\title{
BRASIL: A CONSTRUÇÃO INTERROMPIDA
}

CELSO FURTADO

Rio de Janeiro, Editora Paz e Terra, 1992, 87 páginas.

Por Rosa Marla Vleira, Professora do Departamento de Fundamentos Sociais e Juridicos da EAESP/FGV.

$\mathbf{T}$ eórico do desenvolvimento e um dos "explicadores" clássicos do Brasil, ao lado de Gilberto Freire, Sérgio Buarque de Hollanda e Caio Prado Jr., Celso Furtado construiu ao longo de sua vida uma respeitável obra teórica, levando o mundo subdesenvolvido à condição de objeto privilegiado de estudo. Seus trabalhos em muito inspiraram políticas concretas de governos latino-americanos que, após a Segunda Guerra, procuraram romper o círculo da pobreza e do subdesenvolvimento através da industrialização.

Hoje, porém, o ideólogo otimista do desenvolvimento industrial do Terceiro Mundo cedeu lugar ao intelectual indignado e, ao mesmo tempo, cético. Celso Furtado teme agora pelo futuro incerto do Brasil, cuja construçäo do sistema econômico nacional foi interrompida e o projeto de desenvolvimento, com base na expansão do mercado interno, liquidado. Frente à hegemonia da onda neo-liberal e à ofensiva contrária a toda e qualquer concepÇão social que não esteja tão somente subordinada à lógica de mercado, ele propôe a resistência lúcida.

O seu livro Brasil: a construçäo interrompida, lançado recentemente pela Editora Paz e Ter$\mathrm{ra}$, faz parte desta resistência.

São cinco ensaios que tratam da nova ordem mundial emergente ao fim da Guerra Fria, passando pela discussão da armadilha histórica do subdesenvolvimento, pela retomada de algumas das teses de Raul Prebische por uma nova concepção de desenvolvimento. Um elemento comum une estes ensaios: a busca do entendimento das mudanças na ordem econômica internacional, manifestada a partir da crise dos anos 70 , e do lugar que caberia ao Brasil na lógica capitalista emergente.

Para Celso Furtado o que se assiste hoje, no plano econômico global, é a "degradaçấo sem precedentes dos termos de intercâmbio dos paises exportadores de produtos primários, (a) exorbitante elevação das taxas de jutros, que fez crescer desmedidamente as dividas dos paises do Terceiro Mundo e (as) vastas transferências de recursos fi- nanceiros para os Estados Unidos (página 16).

Nos anos 80 , a economia americana, entrando num quadro de debilidade institucional, tornou-se quase ingovernável, conhecendo o endividamento externo e a desordem fiscal, perdendo a liderança tecnológica e a capacidade interna de gerar poupança para financiar a sua própria reprodução.

Concomitantemente ao declínio da tutela norte-americana, desenhou-se uma multipolaridade no sistema de poder a partir do debilitamento dos sistemas econômicos nacionaís e da emergência de mecanismos de decisões descentralizados e transnacionais.

Nessa situação, em que o poder das empresas transnacionais tendem a tornar obsoleta a idéia de nação, perdem eficácia as políticas macroeconômicas e atrofiam-se os mecanismos de intervenção estatal.

Em verdade, o que preocupa Celso Furtado, frente a este quadro global, é o futuro incerto dos paises subdesenvolvidos, especialmente do Brasil, onde o processo de formação do Estado Nacional se interrompeu precoce mente. Isto, conforme sua linguagem, significa que aqui năo se realizou a difusão dos níveis de produtividade e das tëcnicas produtivas características das nações desenvolvidas, persistindo, tambêm, profundas disparidades regionais de renda.

Sem a referência do sistema econômico nacional o que se tem é o império do mercado em estado puro. Ex para além disto, no caso brasileiro, a possibilidade da inviabilização do país como projeto nacional pois, "a partir do momento em que o motor do crescimento deixa de ser a formaça do mercado interno para ser a integraçäo com a economia internacional, os efeitos da sinergia gerados pela interdependência das distintas regiơes do país desaparecem, enfraquecendo consideravelmente os vinculos de solidariedade entre elas ${ }^{\text {tt }}$ (página 32 ).

Segundo as análises de Furtado, os sistemas econômicos dos grandes países subdesenvolvidos dificilmente sobreviverão ao perderem a força coesiva gerada pelo mercado interno. 
E, no caso concreto do Brasil, o predomínio indiscriminado dos interesses das empresas transnacionais, na ordenação das atividades econômicas, conduzirá a tensōes inter-regionais em nivel explosivo, a rivalidades corporativas, a bolsōes de miséria. Em suma, à invibialização do país como projeto nacional.

Daí a sua angústia em saber "se temos um futuro como nação que conta na construçäo do devenir humano. Ou se prevalecerão as forças que se empenham em interromper o nosso processo histórico de formação de um Estado-nação" (página 35).

Fazendo frente à lógica perversa das forças dominantes, Celso Furtado coloca como imperativo a articulaçã̃o de uma estratégia de resistência que, no Brasil, iria da ativação do po- tencial produtivo interno e da integração dos mercados regionais à formação de uma vontade politica coletiva e transtormadora.

Resta saber: quais serão os agentes efetivos deste processo de resgate nacional? Até onde pode-se pensar num projeto de desenvolvimento autônomo, nesta quadra do século, que leve em consideração as efetivas necessidades das maiorias e que, mesmo não estando simplesmente sob a égide das forças de mercado, subordina-se à lógica do capital?

Passageiro da Utopia, Quixote, lúcido (como ele mesmo se vê), Celso Furtado não responde a estas questões, mas alerta que "como a História ainda não terminou, ninguém pode estar seguro de quem será o último a rir ou a chorar" (página 9).

\section{THE GOOD SOLDIER: A TALE OF PASSION}

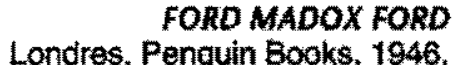

Por Roberto Venosa, Engenheiro, Mestre em Administração Pública pela Universidade de Pittsburgh, Doutor em Sociologia pela EHESS, Paris, Professor Titular do Departamento de Administraçăo Geral e Recursos Humanos da EAESP/FGV e Professor Visitante da University of St. Andrews, Escocia.

C ambridge reinicia seu ano letivo. Lembra um pouco algumas cenas do filme "A Sociedade dos Poetas Mortos". Pais orgulhosos carregam os apetrechos de seus filhos para os diversos colleges. E muito bonito poder ver e sentir a dose de emoção que cada novo aluno traz junto com sua bagagem. Enquanto me dirigia para a Faculdade de Ciências Sociais e Politicas, observando este lufalufa, reparei que dois carros estacionados em frente ao Clare College tinham chapas de diferentes países. Um era francês e o outro era inglês. No francês havia um adesivo escrito em francês que dizia o seguinte: Se wocê bater no meu carro eu amasso a sua cara! No carro inglês estava escrito no para-choque: Nos provavelmente nos encontraremos por acidente.

E exatamente esta pretensa descontração do inglês que Ford derruba, página apos página. $\mathrm{O}$ estilo de Ford tem um quể de preguiçoso e bastante lento, porém corta como bisturi. Seria muito querer compará-lo a um Proust. Certamente não o é. Mas, através da lentidão com que conta a saga de Edward Ashburnham, vamos penetrando a alma britânica. $\mathrm{O}$ que mais impressiona é a lucidez de Ford. Neste ponto, chega muito proximo do proustiano mergulho na alma humana. Ao longo da narrativa, $O$ autor mostra que a saída está aí; mesmo assím, as personagens optam pelo convencional. Sob este aspecto, lembra um pouco Foster, principalmente o Foster de $A$ room with a view pessimamente traduzido como: Uma janela para o amor. Ford năo é o que de mais recente se publicou no Reino Unido porém, para se entender organizações brasileiras, pode-se dispensar a leitura de um Machado de Assis?

Em alguns cursos que conduzi na EAESP/FGV introduzi a leitura de romances. Existe melhor aula de sucessão em pequenas empresas que Os Buddenbrook de Thomas Mann? O Mundo se despedaça do nigeriano Chinua Achebe não pode ser lido como um dos melhores ensaios sobre processo de modernizaçäo? E o olhar antropológico de Yvonne Maggie em Guerra de Orixá não é uma exce- 